\title{
IN THE MEMORY OF KATARINA MILOVUK AND SERBIAN CHARITY
}

\author{
Janicijevic Katarina, ${ }^{1}$ Sazdanovic Maja, ${ }^{2}$ Janicijevic Petrovic A. Mirjana, ${ }^{3}$ Kovacevic Zoran ${ }^{4}$ \\ ${ }^{1}$ Department of Social Medicine, Faculty of Medical Sciences University of Kragujevac, Kragujevac, Serbia \\ ${ }^{2}$ Department of Histology, Faculty of Medical Sciences University of Kragujevac, Kragujevac, Serbia \\ ${ }^{3}$ Department of Ophthalmology, Faculty of Medical Sciences University of Kragujevac, Kragujevac, Serbia \\ ${ }^{4}$ Department of Internal medicine, Clinical Centre of Kragujevac, Kragujevac, Serbia
}

Primljen/Received 20. 06. 2021. god.

Abstract: Katarina Milovuk (Ekaterina Đorđević) was born on August 28, 1844 in Novi Sad of Serbia. She proved to be one of the first women to realize her professional potentials "outside the home hearth" in Serbia, and even more authentically as a true Serbian "Heroine of the Spirit" of the targeted fight for women's rights. With her valuable presentation and views, Katarina Milovuk attracted about 3000 ladies from the most prominent Belgrade families, who accepted the task of taking part in the medical training for girls and women to help Serbian soldiers on the battlefield, and who were more decimated by the typhus epidemic than by lethal bullets of enemies. The main opus (her aim) of her social engagement was the historical struggle for women's rights and activities in the education of women's youth in Serbia. As an active participant in social life in Serbia, she participated in the historical organization of aid for the Serbian army during the wars that Serbia was waging at the time.

Keywords: Katarina Milovuk; Serbian charity and Serbian patriotism; heroine for women's rights; Serbian army.

\section{INTRODUCTION}

Katarina Milovuk (Ekaterina Đorđević) was born on August 28, 1844 in Novi Sad of Serbia, from parents Jovan and Jelisaveta Đorđević. Her father was a brave soldier and an Austrian lieutenant, and at the age of 18 , he fled to Belgrade. As a military officer, he proved himself in the fights against the Turks, in the battle of Sokol, and the battle on the Drina. After the bombing of Belgrade in 1862, he became the commander of the defense of the city of Belgrade. He sent his daughter to high school in the then prestigious educational institution, the Nikolaev Gymnasium at the University of Odesa, where Katarina passed the
Prihvaćen/Accepted 16. 08. 2021. god.

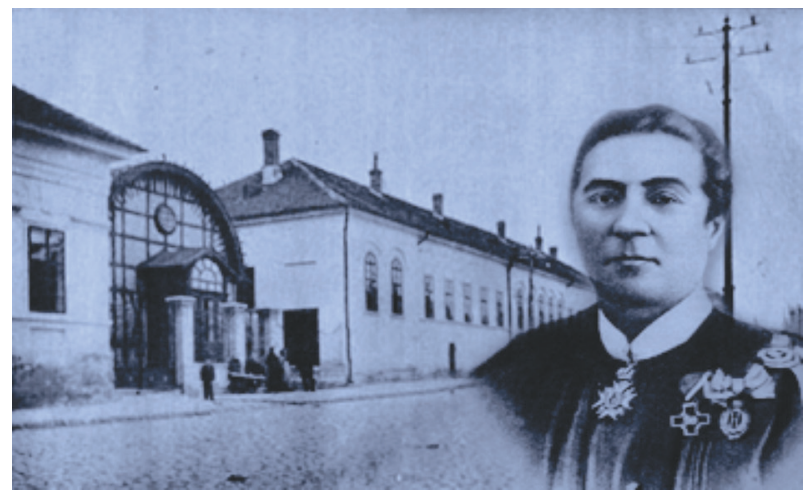

Figure 1. Katarina Milovuk (1863-1913) the real heroine character for women's rights

Photo: Archive of the National Bank of Serbial Belgrade library (1863-1913)

state pedagogy qualifying exam in 1861. After finishing school successfully, Katarina returned to Belgrade. She was a polyglot and could speak Russian, French, German, and English. She also played the piano (1).

She was perceived as a fair, educated, and strict woman, which was a rarity in the traditional Serbian capital between anarchy and autocracy (2).

She proved to be one of the first women to realize her professional potentials "outside the home hearth" in Serbia, and even more authentically as a true Serbian "Heroine of the Spirit" of the targeted fight for women's rights (3). A famous, charitable character, who successfully rose above her time and existence in Serbia, was always great and the first towards all priority tasks (3), shown in Figure 1.

\section{EDUCATIONAL AND PEDAGOGICAL CAREER}

At the age of 19, Katarina Milovuk took over the function of the manager of the newly opened "Higher 
Women's School", and on the recommendation of the Head of the Ministry of Education of Serbia, Ljubomir Nenadović, she then started her educational and pedagogical career through the women's movement in Serbia (4), shown in Figure 2.

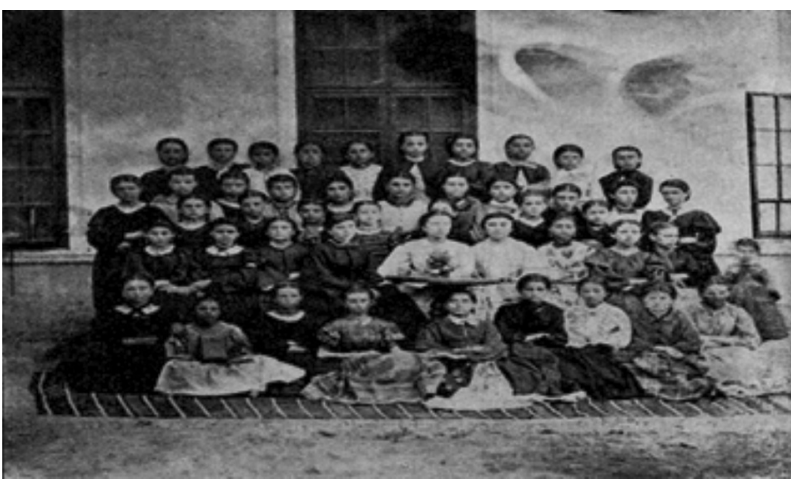

Figure 2. The first class of graduates of "Higher Women's School" 1865/66

Photo: Archive of the National Bank of Serbial Belgrade library: "Higher Women's School": 1863-1913

The "Higher Women's School" raised groups of educated women in Serbia. It educated 25000 female teachers and created four women's high schools: "Women's Teacher's School” (1900), “The First Women's Real High School” (1905), "The Second” (1918), "The Third" at Savamala (5).

She fought for the importance of pro-European and feminist ideas in Serbia with all her strength and skills, so that in 1875 she participated in the founding of the "Belgrade Women's Society", which she successfully managed from 1889 to 1891 (6).

Katarina Milovuk dedicated her professional life to the "Belgrade Women's Society", which is a unique, bright example of a true heroine of Serbian patriotism and charity (7).

In 1865, she got married to Milan Milovuk, a school director of Belgrade "Realka", a lawyer, a professor of history, the founder and first choirmaster of the then Belgrade Singing Society. Since she could not realize herself as a mother, she directed all her inexhaustible life energy towards pedagogical, cultural, educational, traditional, and humanitarian work (8).

She participated in the publication of the national magazine "The Housewife", the first women's magazine in Serbia since 1879. She was an active organizer of volunteer humanitarian work and numerous cultural activities of the society "without borders" (9). The goal of the society was to provide girls with higher general education and to provide educated Serbian teachers for women's primary schools, which began to open and work (by Law, 1847) (10). The society's curriculum included eleven free subjects: the science of Christianity, the Serbian language, general and Serbian history, and geography, natural sciences, arithmetic, pedagogy, dietetics, writing, women's work, gymnastics, domestic technology - cooking skills. Three elective subjects: piano, painting, and foreign language were compulsory and free. Only poor students received books and snacks at that time $(10,11)$.

She gained the love and respect of her people. She enjoyed the honor of the Serbian rulers because the words and deeds of young Katarina were appreciated and influential in all strata of Serbian society. For three decades, she was entrusted with the upbringing of girls aged 11-19, at the end of the 19th century, in then "Semi-Oriental Serbia" in which the "Women's question" was raised (12).

\section{HISTORICAL STRUGGLE FOR WOMEN'S RIGHTS}

She was the co-founder and vice president of the "Circle of Serbian Sisters" together with Delfa Ivanić, Nadežda Petrović, Draga Ljočić, and other Serbian benefactress (1903) (13).

With her valuable presentation and views, Katarina Milovuk attracted about 3000 ladies from the most prominent Belgrade - families, who accepted the task of conducting medical training for girls and women to help Serbian soldiers on the battlefield, and who were more decimated by the typhus epidemic than by the lethal bullets of enemies (14).

She dedicated most of her energy to the fight for national interests, rights, and emancipation of women in the 19th century in Serbia. She initiated the founding of the "Serbian People's Women's Union" which fought for women's suffrage and was its first president (1906). She rose from the first women, who revolted against the "shackles" of patriarchal Serbian society, fighting for women's rights and status. She was an advocate for women. She fought for voting rights, education, the right to work and earn a salary. She founded the "Women's Worker's School" with "Pazar" where the works of schoolgirls were sold, intending to enable women aged 13 to 17 to earn and be independent (15).

Her students were Draga Mašin - a historical great female figure, Nadežda Petrović - a famous painter, Draga Ljočić - a first woman doctor of medicine, Mage Magazinović - a journalist, Zorka Todosić - an actress, and other successful women who followed her path. She was greatly supported by Queen Natalija and other ladies in the government, who attended her lessons, side by side with her students, in the cradle of education in Serbia (16).

She influenced the formation of the correct and realistic attitudes of famous women in Serbia, who 
then faced social prejudices, mistrust, and challenge. She went down in history as a person responsible for the evolution of the female intellectual elite in Serbia. She was the first woman in Serbia who demanded to be registered and active on the voter list in 1897 . In 1900, she submitted a request to the President and the Senate that all independent women and women who supported their families be granted the right to vote. Her appeal for women's suffrage was rejected, but her discipline, spirituality, and vision were not diminished - that she "set the car on the right path" both during the political upheavals and during the wars and tragedies in Serbia. Her demands also affected the constitutional order of Serbia (16).

She was also an active member of the humanitarian "Society for Support and Education of the Poor and Abandoned Children” (17).

With her colleagues from school, she founded the I "Women's Music Society" whose performances and recitals were long remembered among the most prominent citizens of Belgrade at that time (18), shown in Figure 3.

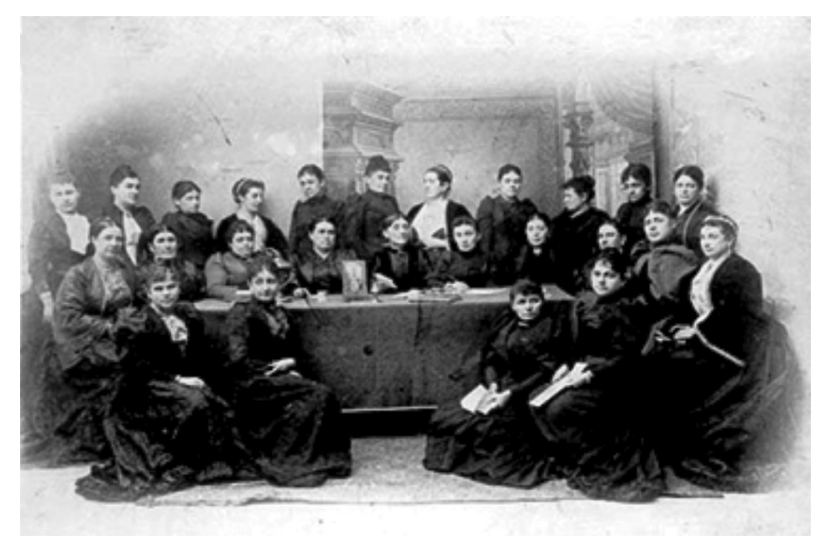

Figure 3. "Women's Music Society" in Belgrade, 1894

Photo: Belgrade City Museum: "The Management of the Belgrade Women's Association”, 1894

\section{HUMANITARIAN WORK: SERBIAN CHARITY} ANE SERBIAN PATRIOTISM

Her indomitable spirit as an "army of mercy" knew no defeat. During the Serbian wars at the time, fighting for liberation and unification, Katarina Milovuk was actively involved in other humanitarian work. Amid the Serbian-Turkish Wars (1876-1878) and the Serbian-Bulgarian War (1885), she trained women as diligent nurses. During the Balkan Wars, she renovated the "Saint Jelena" shelter, which took care of the children of soldiers on the fronts, and paved the way for the medical culture of Balkan-nations (19).
Through her efforts, a sewing workshop was opened within the building of the "Higher Women's School" in Belgrade, where clothes were sown for the needs of the Serbian army, and other important activities, which the "Army of mercy" gave to Serbian-war-history $(20,21)$.

The Serbian sisters left memorial signs through the history of Serbian wars and the signs of the authentic history of Serbian literature [22]. After thirty years, she retired (1893) but did not stop with her other activities. She dedicated herself to translation work and translated from German the novel "Down with Weapons" by baroness Bertha von Suttner (Belgrade, 1899), who won the Nobel Peace Prize in 1905 (22).

She was the author of textbooks used in teaching pedagogy and methodology: Pedagogy - Textbook for Girls of the Higher School of Women (Belgrade, 1866), Methodology - textbook for students of the Higher School of Women (Belgrade, 1866), History of the World in a Short Review for Women (Belgrade, 1871) (23). Just before her doomsday, Katarina Milovuk was one of the successful speakers at the "Congress of the International Alliance for Women's Voting Rights" in Budapest. She was awarded for her humanitarian work "The order of the Serbian Red Cross", in 1877, "The medal of Princess Natalija for zealous service", in 1878, "The medal of Queen Natalia” in 1886, "The order of Saint Sava" in 1905 and two Russian decorations for mercy, humaneness, and charity. The world will still have to reckon with the patriotism of Serbian women - a war epilogue (23).

Katarina Milovuk (among acquaintances called "Milovukica") died in Belgrade, on September 27, 1913, at the age of 69 . In remembrance, Katarina Milovuk and Serbian patriotism not to be forgotten, a street in Belgrade, in the municipality of Zvezdara, bears her name (24).

With this historical text, the authors want to remind of the "Heroine of the Spirit" ahead of her time and gender (the founder of the feminist movement) in the struggle for cultural revival and emancipation of women for the right to work and educate, and for others to meet Katrina Milovuk: the most influential, most educated woman in Serbia in the second half of the nineteenth century (24).

In memory of remembrance and gratitude, to pay tribute and preserve from eternal oblivion "Heroine of the Serbian spirit - When women became citizens in Serbia", and their culture of femininity, existence, and power in society $(24,25)$ !

\section{IN CONCLUSION}

The main opus (the aim) of her social engagement was the historical struggle for women's rights and ac- 
tivities related to the education of young women and girls in Serbia. As an active participant in the social life in Serbia, she also participated in the historical organization of aid for the Serbian army during the wars that Serbia was waging.

\section{Acknowledgment}

None.
Conflict of Interests: The authors declare that there are no conflicts of interest related to this article.

Funding: None

\section{Licensing}

This work is licensed under a Creative Commons Attribution 4.0 International (CC BY 4.0) License

\title{
Sažetak
}

\section{SEĆANJE NA KATARINU MILOVUK I SRPSKO DOBROČINSTVO}

\author{
Janicijevic Katarina, ${ }^{1}$ Sazdanovic Maja, ${ }^{2}$ Janicijevic Petrovic A. Mirjana, ${ }^{3}$ Kovacevic Zoran ${ }^{4}$ \\ ${ }^{1}$ Department of Social Medicine, Faculty of Medical Sciences University of Kragujevac, Kragujevac, Serbia \\ ${ }^{2}$ Department of Histology, Faculty of Medical Sciences University of Kragujevac, Kragujevac, Serbia \\ ${ }^{3}$ Department of Ophthalmology, Faculty of Medical Sciences University of Kragujevac, Kragujevac, Serbia \\ ${ }^{4}$ Department of Internal medicine, Clinical Centre of Kragujevac, Kragujevac, Serbia
}

Katarina Milovuk (Ekaterina Đorđević) rođena je 28. августа 1844. u Novom Sadu u Srbiji. Dokazala se kao jedna je od prvih žena, koja je u Srbiji ostvarila svoje profesionalne potencijale „izvan kućnog ognjišta“, a još autentičnije kao prava srpska „Heroina duha" ciljane borbe za ženska prava. Svojim vrednim izlaganjem i stavovima Katarina Milovuk je privukla oko 3000 dama iz najuglednijih beogradskih porodica, koje su prihvatile zadatak da održe medicinske obuke za devojke i žene, kako bi pomogle srpskim vojnicima

\section{REFERENCES}

1. Stojaković G. Znamenite žene Novog Sada [Knj. 1]. Novi Sad: Futura publikacije; 2001.

2. Perović L. Između anarhije i autokratije srpsko društvo na prelazima vekova (XIX-XXI). Beograd: Ogledi, Helsinški odbor za ljudska prava u Srbiji, 2006.

3. Cvetković K Kosara. Katarina M. Milovik. Srpkinja: njezin život i rad, njezin kulturni razvitak i njezina narodna umjetnost do danas. Knjiženstvo. 1913: 69-70.

4. Stankov Lj. Katarina Milovuk (1844-1913): i ženski pokret u Srbiji. Beograd: Pedagoški muzej, 2011.

5. Vasojević AN. Prve srpske učiteljice. Uzdanica. 2014; 11(1): 59-72

6. Zaharijević A, Lončarević K. Kratki istorijski pregled važnih datuma za feminizam u Srbiji i svetu. Neko je rekao feminizam? Kako je feminizam uticao na žene XXI veka. Beograd: Heinrich Boell Foundation; 2014.

7. Cameron J, Gipson-Graham JK. Feminising the Economy: Metaphors, strategies, politics. Gender, Place and Culture. Journal of Feminist Geography. 2003; 10(2): 145-57.

8. Arsenović-Pavlović M, Stanisavljević-Rakić V, Rajović-Đurašinović V. Feminizacija vaspitanja - od tradicije ka savremenosti. Beograd: Etnoantropološki problemi 6; 1989: 67-83.

9. Prošić-Dvornić M. Žensko pitanje u Srbiji krajem XIX i početkom XX veka i časopis „Domaćica“ (1879-1914). Glasnik Etnografskog muzeja u Beogradu. 1985; 34: 47-70. na ratištu, a koji su bili više desetkovali od epidemije tifusa, nego od neprijateljskih ubojnih metaka. Glavni opus (cilj) društvenog angažovanja Katarine Milovuk bila je istorijska borba za prava žena i aktivnosti u obrazovanju ženske omladine u Srbiji. Kao aktivni sudionik društvenog života u Srbiji, i u vreme ratova koje je Srbija tada vodila, učestvovala je i u istorijskom organizovanju pomoći za srpsku vojsku.

Ključne reči: Katarina Milovuk; srpsko dobročinstvo i patriotizam; heroina za ženska prava; srpska vojska.

10. Korićanac T, Taneska Lj. Domaćica: organ Ženskog društva i njegovih podružnica. Beograd: Beogradsko žensko društvo 1875-1941; 1995.

11. Femić B. Od listova za domaćice do glasila feminizma. Beograd: NUNS press, Novi magazin, 2013.

12. Božinović N. Žensko pitanje u Srbiji: u XIX i XX veku. Beograd: Feministička izdavačka kuća 94, 1996.

13. Viktorović M. O Kolu srpskih sestara. Bratstvo, Društvo Sveti Sava. 2011; 15: 203-14.

14. Dedić M. Kolovođa srpskih sestara Katarina Milovuk. Beograd: Večernje Novosti, 2014.

15. Ćorović Lj. Vek i po od osnivanja Više ženske škole u Beogradu. Knjiženstvo. 2013; 3.

16. Ćunković S. Školstvo i prosveta u Srbiji u XIX veku. Beograd: Pedagoški muzej; 1971.

17. Nikolov M. Školovanje ženske mladeži u Srbiji do 1914. Srbija u modernizacijskim procesima, 2, Beograd; 1998.

18. Korićanac T, Taneska Lj. Beogradsko žensko društvo, 1875-1941. Beograd: Muzej grada, Pedagoški muzej, 1995.

19. Pavlova VT. Aspects historiques de la culture medicale des peuples balkaniques (fin du 18-e siècle-début du 19e siècle) [Historical aspects of the medical culture of Balkan nations (end of 18th century-beginning of 19th century)]. Sante Publique (Bucur). 1968; 11(4): 441-8. French.

20. Stolić A. Sestre Srpkinje. Beograd: Evoluta, 2015.

21. Milanović J. Vojska milosrđa. Knjiženstvo. 2015; 5:3. 
22. Dojčinović B, Vraneš A, Bečanović-Nikolić Z. Kniženstvo, teorija i istorija ženske književnosti na srpskom jeziku do 1915. godine. Beograd: Filološki fakultet Univerzitet u Beogradu; 2015. ISBN 978-86-6153-30-8.

23. Stolić A. Sa rodoljubljem srpskih žena imaće svet još da računa. Prvi svetski rat, Srbija, Balkan i velike sile (zbornik radova, knj. 30). Beograd: Istorijski institut: Institut za strategijska istraživanja; 2015: 383.

24. Pavićević A. Žene i njihova moć u društvu. Glasnik Etnografskog instituta SANU. 1999; 48: 74-94.

25. Petrovic E. Kultura ženstvenosti. Etnološke sveske. 1985; 6: 51-6.

\section{Correspondence to/Autor za korespondenciju}

Doc dr Katarina Janicijevic,

Department of Social Medicine, Faculty of Medical Sciences University of Kragujevac, Kragujevac, Serbia Svetozara Markovica 69, 34000 Kragujevac, Serbia

E-mail:kaja.andreja@yahoo.com

Tel: +381642183797 